Opinions of primary education teachers on the advantages and disadvantages of on-line teaching

Delia Muste 


\title{
Opinions of primary education teachers on the advantages and disadvantages of on-line teaching
}

\author{
Delia Muste ${ }^{\mathrm{a}^{*}}$ \\ ${ }^{a}$ Faculty of Psychology and Educational Sciences, Babeş-Bolyai University, 7 Sindicatelor Street, 400015, Cluj-Napoca, Romania \\ *Corresponding author: delia.muste@ubbcluj.ro
}

\section{Abstract}

\section{Keywords:}

online teaching, digitization, advantages, disadvantages, teachers, technology
In Romania, schools were closed, courses were suspended on March 11, 2020. The Ministry of Education and Research sent teachers the recommendation to conduct online courses at home. Over the following weeks, this recommendation was supplemented by others, the Ministry recommend that teachers take online courses, without making them compulsory. On March 20,2020, the Ministry of Education approved the Methodology on the distance continuation of the educational process in quarantine conditions that establishes the way to continue the educational process in primary, secondary and high school institutions in quarantine conditions. The methodology establishes the obligation to conduct distance learning courses through various online platforms (eg Viber, Whatsapp, Facebook, Google Classroom, Zoom, etc.) and allows the assessment of students during this period and the registration of grades in the catalog.

The large number of platforms available online for conducting such courses, as well as the lack of a national or local decision on the use of a single platform, has generated quite a bit of confusion among teachers and especially among students. We wanted to find out the opinions of primary school teachers regarding the advantages and disadvantages they perceive regarding online teaching, through interviews with them.

\section{Zusammenfasung}

\section{Schlüsselworte:}

Online-Unterricht, Digitalisierung, Vorund Nachteile, Lehrer, Technologie
In Rumänien wurden die Schulen geschlossen und die Kurse am 11. März 2020 ausgesetzt. Das Ministerium für Bildung und Forschung sandte den Lehrern die Empfehlung, Online-Kurse zu Hause durchzuführen. In den folgenden Wochen wurde diese Empfehlung durch andere ergänzt. Das Ministerium empfiehlt den Lehrern, Online-Kurse zu belegen, ohne sie zu verpflichten. Am 20. März 2020 genehmigte das Bildungsministerium die Methodik zur Fortsetzung des Bildungsprozesses unter Quarantänebedingungen, die den Weg für die Fortsetzung des Bildungsprozesses in Primar-, Sekundar- und Hochschuleinrichtungen unter Quarantänebedingungen festlegt. Die Methodik legt die Verpflichtung fest, Fernlehrgänge über verschiedene Online-Plattformen (z. B. Viber, WhatsApp, Facebook, Google Classroom, Zoom usw.) durchzuführen, und ermöglicht die Bewertung von Studenten während dieses Zeitraums und die Registrierung von Noten im Katalog.

Die große Anzahl von Plattformen, die online für die Durchführung solcher Kurse verfügbar sind, sowie das Fehlen einer nationalen oder lokalen Entscheidung über die Verwendung einer einzigen Plattform haben bei Lehrern und insbesondere bei Schülern zu großer Verwirrung geführt. Wir wollten die Meinungen der Grundschullehrer zu den Vor- und Nachteilen, die sie im Online-Unterricht wahrnehmen, durch Interviews mit ihnen herausfinden.

\section{Introduction}

The COVID-19 pandemic has fundamentally changed the way teachers around the world teach. The familiar atmosphere of the classroom was replaced by the necessary distance learning in an emergency. But what could schools and teachers do to successfully integrate online learning into the future? How should it proceed? Given that the pandemic has led to the mass closure of schools in Europe, many countries have taken steps to limit the disruption of education, which has necessitated the transition to online and distance learning in both secondary and primary schools.
The interest of NGOs and national and European administrative structures in the specifics of online teaching and its strengths and weaknesses has materialized in a series of educational policy documents developed recently or several years ago, designed to bring completions and clarifications. related to this phenomenon, during or before the pandemic context. Thus, U.S. The Department of Education (2010), the European Union through the Eurydice Report (2020) or the think tank Expert Forum (2020) analyzed from various perspectives the situation of digitalization at international and national level, accurately outlining a profile of the factual situation. 
We already know that effective online teaching does not just mean taking the content of the lesson and transmitting it using technology. The online learning environment comes with specific challenges and resources, which require both teachers and students to adapt and change the way they work. Digital learning is increasingly replacing traditional educational methods. No matter how much or how little technology is integrated into the classroom, digital learning has come to play a crucial role in education. How? By making students more interested in learning and broadening their horizons Digital tools and technology develop effective self-teaching skills for students. They become able to identify what they need to learn, find, and use online resources, and apply the information to school, homework and projects. This increases their efficiency and productivity.

In addition to the increased level of student involvement, digital tools and technology develop critical thinking skills, which underlie the development of analytical reasoning. Children who explore open-ended questions using their own imagination and logic learn to make decisions more coherently, as opposed to mechanically memorizing lessons in the textbook.

\section{Problem statement}

Given the changes brought about by the introduction of online teaching, 6 months away from the start phase, we intended to find out what is the opinion of teachers who teach in primary education (rural and urban) on the strengths and weaknesses of this digitized process. We believe that a better knowledge of these aspects can lead us to a better management of the factual dictation, with positive effects on students, teachers, or decision makers.

\section{Research questions}

We considered it necessary to find out what are the advantages and disadvantages of online teaching that teachers for primary education perceive and what is their opinion on how these distance learning activities take place. For this purpose, we invited 10 primary school teachers ( 7 from urban and 3 from rural) to participate to an on-line indepth interview based on two open-ended questions?

1) Mention at least 5 benefits brought to you by online learning, in the order of the importance

2) Mention at least 5 difficulties brought to you by online learning, in order of their importance

\section{Findings related with research question no. 1}

Following 2 meetings for discussions on the proposed topic (one related to advantages and another to disadvantages), some basic ideas were crystallized, which we will detail separately, in accordance with the answers provided by the interviewees.

\section{Advantages of online teaching for teachers}

- Because parents are partners of younger children in the teaching process, more consistent relationships can develop between school and family, parents can understand more easily and empathize more with the effort of a teacher. Thus, the teacher-parent relationship also develops.

- Parents can explore with their children different platforms, online tools and thus learning takes place in adults as well.

- At the management level of the classroom, the dynamics change and parents can provide the right framework for learning.

- Adapting to online teaching encourages teachers to collaborate with each other, sharing their materials and teaching practices much more easily, at great distances.

- There are teachers who have previously participated in or taught online courses and who are more familiar with some methods. Many of them want to share their knowledge with those who need support.

- The flexibility of making the schedule is an aspect mentioned as advantageous, because it allows the teacher to make decisions related to establishing synchronous and asynchronous activities with students

- The chance to meet students in a new setting is another advantage mentioned by teachers

- New learning opportunities that can be capitalized as a way of restructuring the contents and the traditional teaching style

- The possibility for teachers to work together, as a team, is considered a very important element in managing the crisis situation, as it facilitates the possibility to make decisions together for the benefit of students and to support each other.

\section{Advantages of online teaching for students}

- Moving courses online encourages students to have more autonomy in learning, making the most of their creativity.

- Temporarily moving the learning process to the online sap, can sustain the pace of learning and can increase students' confidence in their own abilities and resources to be self-taught.

- The student's comfort is higher being in a personal space

- There is no more noise, children have more time to rest, they do not have to wake up very early in the morning to take public transport

- Students' curiosity can be more consistently stimulated through technology that can do homework more interesting

- In some cases, students who were more disinterested in class lessons became more involved in online

- The flexibility of the schedule ensures an increased freedom for the student to organize his program in agreement with other aspects that until now were not considered by the school (for example the professional program of the parents) 
- The possibility for the teacher to record an entire sequence or lesson, which the student can access whenever he feels the need for clarification or additional support in understanding

- Some students feel more comfortable expressing their opinion online, feel listened to and encouraged to speak

- The introduction of interactive elements facilitated the transition to online and students became more interested in the courses, understood more easily, and became more active in live meetings.

- Some students see this form of teaching as something new, treat it with curiosity.

\section{Findings related with research question no. 2}

\section{Disadvantages of online teaching for teachers}

- The difficulty of knowing the real load with homework of students where there is no communication between teachers

- Lack of sufficiently high-performance equipment or insufficient equipment (eg families with teachers and students and must use equipment at the same time),

- In some cases, teachers were caught unprepared and did not know how to use the platform. Those who already used certain online tools adapted more easily

- Accommodation with applications, which was compensated in some cases with individual study (frequent)

- The relationship with the parents was difficult in some cases because they did not have enough skills to use the technology

- Lack of appropriate equipment

- Teachers consider that a major shortcoming of the platforms provided when going online is the lack of direct interaction with students

- Teachers fail to track students and see their level of assimilation of the information transmitted, and the assessment process is thus difficult.

- Teachers were trained from tutorials and did not receive support because they did not master technical skills

- Teachers do not feel ready to go online and adapt courses in this format.

- Sometimes they feel demotivated to make the switch, do not have the necessary technical equipment or the internet connection does not allow them to hold live meetings with students. They feel that they do not have the skills to use the various online platforms available.

- Working with very large classes, online debates are long and tiring, and preparing materials takes a long time.

- A major drawback of online teaching platforms is the lack of direct interaction with students. Teachers fail to track the progress of students and see their level of assimilation of information transmitted and the assessment process is thus difficult.

\section{Disadvantages of online teaching for teachers}

- Impossibility of all students to participate in online lessons,

- Limiting human contact,

- Lack of an e-mail address (in urban and rural areas)

- Using multiple applications at the same time creates overwork and confusion

- The family does not have the necessary technical equipment for the student to attend classes

- Poor internet connection (rural and urban) or missing

- The reaction of the students was positive at the beginning, but the interest is lost along the way

- Children lack interaction with school, socialization

- Some students do not have devices and have to wait for their parents / depend on their parents' service schedule

- Some activities can be tiring and overwhelm them / some students are stressed

- The learning process is not uniform, and some students do not adapt easily and do not understand the content of the lessons

- Students do not know how to use the platforms provided or, in the case of young children, parents do not know and therefore cannot support them

- In some cases, mentioned by teachers, families have the necessary technical equipment, only that in a family there are several students, sometimes teachers, which means that not everyone can have access to the equipment.

\section{Conclusions}

Although distance learning offers definite benefits to teachers and students (continuity, flexibility, and mutual support), teachers make efforts to adapt to online teaching due to the short time available. In addition, it is difficult for them to ensure that all students, especially the disadvantaged or young, will remain motivated and will continue to participate in online classes.

The positive aspects mentioned by the respondents were related to innovation, ie the freedom to experiment in the teaching activity, the flexibility and the wide range of work tools and the involvement of students and the improvement of the relationship with them.

Almost all teachers reported difficulties, the most common being access to technology for both students and teachers, as well as the increased workload and stress level associated with working from home. Several difficulties were identified related to the support provided to students, as well as to the level of digital competence of both students and teachers.

Respondents believe that concrete support in the form of more educational resources would help them overcome obstacles. Several clear guidelines from the Ministry of Education, as well as professional development activities such as quick courses on online teaching and opportunities 
to exchange resources, ideas and solutions to obstacles, would also be useful.

These findings give decision makers and school principals a few early indications that distance / online teaching and learning, although difficult, can have lasting positive effects, opening up interesting perspectives for innovation and new ways of working, especially when supported. of adequate and timely professional development efforts.

If we look at the positive side, however, many teachers see this crisis as an opportunity to learn new skills, to learn more about themselves and their students. Most respondents feel that they have a responsibility to be with their students and to guide them through this period.

\section{Authors note:}

Delia Muste has a $\mathrm{PhD}$ in education sciences and is a lecturer at the Department of Education Sciences, Faculty of Psychology and Education Sciences, Babeş-Bolyai University Cluj-Napoca, Romania. Her areas of interest and research cover several domains (including interdisciplinary ones), such as the educational communication, educational alternatives, civic education, time management applied in education and teacher training programme.

\section{References}

https://www2.ed.gov/rschstat/eval/tech/evidence-basedpractices/finalreport.pdf (accessed in 10 october 2020). https://op.europa.eu/en/publication-detail//publication/d7834ad0-ddac-11e9-9c4e01aa75ed71a1/language-ro/format-PDF (Accessed at 12.10.2020).

https://expertforum.ro/scoalapentrudemocratie/files/2020/ 04/PB-84-scoli.pdf (Accessed at 12.10.2020). 